\title{
Microfinance Performance. Do Good Institutions Matter?
}

\author{
Peter W Muriu \\ School of Economics, University of Nairobi, Kenya
}

\begin{abstract}
Existing literature suggests that microfinance institutions (MFIs) are likely to operate in different institutional environments. Unlike retail banks, MFIs bridge two institutional settings: the formal environment, in which they source their funding and in which they are legally embedded, and the informal environment, in which they operate. This study contributes to a growing literature on microfinance performance by investigating whether the institutional environment of the host country matters for MFIs performance. Using panel data corresponding to 167 MFIs for the period 1997-2008, System GMM Estimator is applied to determine the extent to which institutions affect microfinance performance. Estimation results reveals that MFIs profitability is non-negligibly driven by the surrounding institutional environment. Specifically, MFIs are more profitable in countries with political stability, effective and predictable rule of law. However, the magnitude of the effect is sensitive to MFIs age.

JEL classification: E02; G21
\end{abstract}

Keywords: Microfinance Institutions; Profitability, Institutional Environment

DOI: $10.7176 /$ RJFA/11-16-07

Publication date:August $31^{\text {st }} 2020$

\section{Introduction}

The Microbanking Bulletin $2010^{1}$ shows that for the years 2005-2008, microfinance institutions (MFIs) operating in Africa consistently posted negative profits. On the contrary, those operating in other continents recorded positive profits over the same time period. Are there constraints unique to Africa's environment that hinders MFIs profitability? This paper investigated the extent to which microfinance profitability depends on institutions of the host country.

Existing literature suggests that different MFIs are likely to correspond to different levels of poverty, and, implicitly, to different institutional environments (Chu, 2007). Much of the literature is however on corporate governance. Studies on this front include performance and corporate governance (Mersland and Strøm 2009), external control exercised by stakeholders (Hartarska 2009), governance history (Mersland 2009a), cost of ownership (Mersland 2009b), ownership structure and transparency (Mersland and Strøm 2008), organizational governance (Hartarska 2005). There is hardly any rigorous analysis and evidence documented on the influence of country level governance institutions on MFIs profitability. This study is a first attempt to quantify this contribution and fill an important research gap.

Good governance is a prerequisite to secure property rights, enforcement of contracts and for the provision of adequate public goods (Dixit, 2009). One would expect a country's institutional environment to remain the same over time, in which case institutional variables may be considered exogenous to MFI profitability. However, in many developing countries, institutional quality can deteriorate sharply and periodically as a result of political instability, policy reversals, or fiscal austerity programs (Aron, 2000) and even historical origin of a country's laws (La Porta et al 2008). Using stochastic frontier analysis, Lensink et al (2008) examine whether the efficiency of foreign banks depends on the institutional quality of the host country and on institutional differences between the home and host country. Hasan, et al (2009), extends this study by investigating the impact of 'good' institutions on bank efficiency in China. It is however not clear from these studies how a country institutional development would influence microfinance profitability.

The relationship between microfinance profitability and the institutional environment cannot be extrapolated from studies on traditional retail banking industry. There are clear and substantial differences. MFIs serve a more economically marginal clientele and finance small and medium enterprises which are mainly informal (Cull, et al 2009a; c). Their service delivery technologies that include screening and monitoring may therefore significantly differ from that of the conventional retail banks. Moreover, a number of MFIs are subsidized, indefinitely or at least during an initial start-up phase (Armendáriz and Morduch 2010).

Stylized facts show that financial sector across Africa economies operate within weak institutional environments (Anayiotos and Toroyan 2009). Africa is characterized by weak; judicial system, bureaucracy, law and order, property rights and political incentives (Creane, et al 2004). Of the 30 Africa countries covered in the 2011-2012 Global Competitiveness Index of the World Economic Forum; 24 scored below 4, placing them among the worst 58 countries. Additionally, 38 of the 45 Africa countries that are covered by the 2012 Economic Freedom Index (of the Heritage Foundation) are considered either "mostly unfree" or "repressed".

$1 \mathrm{http} / /$ www.themix.org/publications/microbanking-bulletin/2010/09/microbanking-bulletin-september-2010-issue-no-20-0 
This study therefore sought to address the question; does the institutional environment matter for MFI's profitability? Put differently, do MFIs perform better in the context of well-developed institutions, or do good institutions crowd out MFIs? These are broad questions that do not find unambiguous answers in economic theory. Beyond evaluation of MFI profitability, answers to these questions may provide indirect evidence on how microfinance fits into the process of development in line with Ahlin and Jiang (2008) theoretical postulations. MFIs are very different from retail commercial banks from an institutional perspective. Unlike banks, MFIs bridge two institutional settings: the formal environment, in which they source their funding and in which they are legally embedded, and the informal environment, in which they operate. MFIs typically do not rely on formally enforceable contracts when they give out loans. This "bridging" of two institutional settings is specific to MFIs active in low-income communities (De Soto, 2000; Rivera-Santos, et al, 2012). For instance, the reliance on enforceable contracts through the rule of law applies to retail banks, when they give out loans but not for MFIs, but who on the other hand rely on them when they secure their own funding.

This study makes contributions to policy and existing literature fourfold. First, it is timely in view of the broader issue of how governance may affect financial inclusion, especially among the poor. Second, it is of policy interest to the regulators. MFIs may for instance require a lower risk contribution on their investment in economies with strong institutions. Third, although most MFIs use joint liability or informal mechanisms to secure high levels of repayment, MFIs that employ the standard individual lending contract might benefit from adherence to the rule of law. Well-functioning supporting institutions that help to enforce contracts such as courts may therefore enhance MFI profitability. While this proposition seems straightforward, no serious and rigorous empirical work has been carried out in microfinance to support it. Fourth, microfinance has become attractive to foreign capital investment and foreign investors place a greater emphasis on country institutional context when selecting an investment location (Bevan et al. 2004).

The rest of this paper proceeds as follows. In the next section we review the related literature. In section 3 , we present and discuss methodology and the data employed. In section 4, we present the empirical results and explore a number of robustness checks. Section 5 concludes the paper.

\section{Previous evidence}

The influential study of North (1990) raised awareness of the role of institutions in establishing incentives for economic activity in general and for investment in particular. Unfortunately, hardly any empirical evidence has been provided on this issue in the microfinance front. Much of the empirical work on MFI performance has focused on institutions' success or otherwise with a view of arriving at best practices (Patten, et al 2001; Mosley and Rock 2004; Kaboski and Townsend 2005; Cull, et al 2007; Hartarska and Nadolnyak 2008; Caudill, et al 2009; Armendáriz and Morduch 2010). Although Ahlin et al. (2011) in particular focus on macroeconomic environment and macro-institutional environment, their focal MFI performance indicators are operational selfsufficiency and extensive and intensive MFI growth. Operational self-sufficiency as a measure of MFI performance can be misleading as it lumps together genuine operating net revenue with transfers and financial sustainability does not imply profitability (Armendáriz and Morduch 2010).

Another study that has utilized institutional environment as a control variable is Hartarska and Nadolnyak (2007) but whose focus is on the impact of regulation on MFI sustainability. With regard to institutional environment, this paper makes a point related to Ahlin et al. (2011) and Hartarska and Nadolnyak (2007), but differs from both mainly in econometric methodology that tackles endogeneity besides using a richer set of MFI controls. We view the results as complementary and in agreement where they overlap.

The law and finance theory posits that the different legal traditions that emerged in Europe over previous centuries and were spread internationally through conquest, colonization, and imitation help explain crosscountry differences in investor protection, the contracting environment, and financial development today (La Porta et al 1998). However, contrary to law and finance theory, Qian and Strahan (2007) investigate how financial contracts respond to the legal and institutional environment. Consistent with La Porta, et al (2000, 2002), they find that strong creditor rights enhances loan availability as lenders are more willing to provide credit on favourable terms. In Africa and for countries with similar financial liberalization efforts, McDonald and Schumacher, (2007) finds that those with stronger legal institutions and information sharing have deeper financial development. This confirms Demirgüç-Kunt, et al (2006).

Although theory shows that corruption retards the development process to an even greater extent than taxation (Fisman and Svensson 2007), the role of corruption in bank lending is not straightforward. Corruption may reduce the portfolio-assets ratio and therefore suppress asset and liability growth (Demetriades and Fielding 2011). On the contrary, bureaucratic corruption may not necessarily be bad for business. Corruption may serve to grease the wheels of commerce, by reducing transaction cost and lowering the cost of capita (Pierre-Guillaume and Sekkat 2005). Indeed, Cai, et al. (2011) shows that although bribery to government officials both as "grease money" and "protection money," has a significantly negative effect on firm performance, its negative effect is much less pronounced for those firms located in cities with low quality government service, those who are 
subject to severe government expropriation, and those who do not have strong relationship with suppliers and clients.

There is however large empirical literature suggesting that corruption undermines confidence in and the functioning of institutions, (see Clausen, et al 2009, for a a thorough discussion of the identification problem in that context). Using controlled field experiment on corruption, Armantiera and Amadou (2011) concludes that monitoring and punishment can deter corruption, but they cannot reject that it may also crowd-out intrinsic motivations for honesty when intensified. Along the same vein, Weill $(2011 \mathrm{a}, \mathrm{b})$ shows that while the overall effect of corruption is to hamper bank lending, it can nevertheless alleviate firm's financing obstacle which is consistent with theoretical postulations that corruption may greese wheels of commerce. ${ }^{2}$

Efficient economic regulation reduces government and market failures while assuring that the markets function without distortions (Djankov, 2009; Barseghyan, 2008; Crafts, 2006; Klapper, et al 2006; Loayza et al. 2005). This is important for the development of private investments. Ciccone and Papaioannou (2007) shows that in countries where it takes less time to register new businesses, there has been more entry in industries that experienced expansionary global demand and technology shifts. Demirgüc-Kunt, et al (2004) finds that rigid regulations on bank entry and bank activities lead to an increase of the cost of financial intermediations.

Without a proper protection of intellectual property rights, firms fear expropriation of investment in intellectual property and intangible assets. Djankov, et al (2007) investigate credit institutions in 129 countries over 25 years and show that contract rights and enforcement institutions influence the development of financial markets. Their finding is consistent with Djankov et al. (2006) who show that secure property rights are a significant predictor of firm reinvestment. Based on cross-country evidence, Acemouglu and Johnson (2005) conclude that property rights institutions tend to be far more important than contracting institutions and that it is harder to avoid government expropriations. Further cross-country evidence suggests that countries with worse property rights tend to have lower aggregate investment and worse access to finance (Claessens and Laeven 2003; Acemoglu et al. 2001).

There also a few studies that have examined the role of political stability in the financial intermediation process. Roe and Siegel (2009) for instance, draws a link between political stability; economic growth and financial development, which is consistent with the argument advanced by Rajan and Zingales (2003) in exploring political economy as determinants of financial development. Evidence on the possible link between political stability and rule of law on financial inclusion in many Africa economies is provided by Anayiotos and Toroyan (2009). Evidence of the impact of political stability, government effectiveness, rule of law, and regulatory quality on financial development is documented by Gani and Ngassam (2008).

The literature survey presented in this section underscores the importance of institutional reforms for financial intermediation. We posit that institutions matter for microfinance profitability because they influence the costs of transactions and the efficiency of microbanking. This may have an impact on MFIs profitability.

\section{Methodology and data}

\subsection{Theoretical predictions}

Institutions ${ }^{3}$ affect performance of financial intermediaries because they influence the costs of transactions and the efficiency of production (Aron, 2000). Overall political stability (PS) and the quality of contract enforcement in the country may affect the extent of moral hazard that MFIs face when advancing loans. Institutions promoting the rule of law may enhance MFIs' ability to enforce loan contracts, and hence increase growth (Messick, 1999). This has implications on profitability.

The Voice and Accountability (VA) index defines the ability of citizens to hold politicians accountable, including freedom of press, association, and media. Conceptually, therefore VA and corruption (COR) are either related by definition or causally related. Higher transparency of government policymaking would especially benefit foreign MFIs operating in Africa. We predict a positive association between VA and MFI profitability.

Political parties with a long term vision (PS) will not support highly ineffective government (GE) and prefer the rule of law $(\mathrm{RL})$ to the rule of the jungle. When government transitions are guided by the constitution, rather than coups, government officials are more likely to have a longer time focus and to seek investment for growth

2 Further evidence of corruption on West Africa banks is documented by Demetriades and Fielding (2011), for a cross-section of 120 countries and a panel of 70 countries by Dreher and Schneider (2010), cross-country micro evidence by Bartha et al (2009) and in SubSahara Africa by Bissessar, (2009). Evidence for a link between corruption and confidence in public institutions is also discussed in Bianca, et al (2009) while that of corruption and competition in public administration is documented in Gioacchino and Franzini (2008). Direct evidence on the link between bribes and companies' operating cost is documented by Ng, (2006), Gelos and Wei (2006). Corruption also imposes substantial economic costs, particularly in less developed economies (Olken, 2007; Lambsdorff, 2007; Cho, et al 2007; Chang, et al 2006; Ito 2006; Catterberg and Moreno 2005; Svensson, 2005; Beck et al. 2005

3 In the empirical literature the term institutions encompass a wide range of indicators, including institutional quality (the enforcement of property rights and governance), political instability (riots, coups, civil wars), characteristics of political regimes (elections, constitutions, executive powers), social capital (the extent of civic activity and organizations), and social characteristics (differences in income and in ethnic, religious, and historical background). 
rather than corrupt transfers (COR). Thus, PS is related to COR, RL and GE either causally or by definition. Higher values of PS impacts positively on MFIs profitability especially if MFIs have relatively high loan loss provisions because of the inherent security costs associated with unstable political regimes ${ }^{4}$. We therefore postulate a positive relationship between PS and MFI profitability.

When a government is effective (GE), it makes transfers that are transparent (VA). Similarly, effective governments use public resources for public gain, so that the public expenditure is not a deadweight loss (RQ). Effective governments charge for services provided to the citizens which ensures minimal deadweight loss. Indeed the Global Competitiveness Report 2009-2010 points to government inefficiency as the worst obstacle for doing business in most Africa economies. Foreign MFIs are assumed to face more difficulty in dealing with the host economy bureaucracy. We therefore expect a positive association between government effectiveness and MFIs profitability.

The impact of the rule of law $(\mathrm{RL})^{5}$ is felt through the effectiveness and predictability of the judiciary. This is important for contract enforcement. Rule of law is intended to create a stable environment within which micro borrowers operate; but it may also make it harder for small and medium enterprises to operate thus avoiding regulations and tax (COR). Thus, RL and COR are also related by definition or causality. Firms post a higher investment rate when most of the business disputes are resolved through the court system (Long 2010). However, if going to court is time consuming, this translates to higher costs. The legal system boosts firms' performance by improving the trust needed for transaction relationships (Johnson et al. 2002). Similarly Laeven and Woodruff (2008) finds that firm size increases as a result of the quality of local legal system. We therefore predict a positive relationship between effective rule of law and MFI profitability.

Corrupt deals (COR) are a characteristic of a black market, where contracts are enforced not by public law but by private players. Corruption is a costly, hidden (in the absence of VA) and usually illegal transfer of revenues in the absence of RL. Government officials often collect bribes in exchange for a license or service or for exemptions to rules or taxes (lack of GE). Additionally, corruption undermines the rule of law thereby damaging the legitimacy of the political process (Knox, 2009). Higher levels of corruption may also hinder small and medium enterprises ability to operate and grow (see e.g. Fisman and Svensson, 2007). On the contrary, when corruption does not hinder micro-enterprises growth directly, its main effect may be lowering wages (Ahlin, et al 2011). We therefore predict a positive relationship between effective control of corruption and MFIs profitability.

When a government establishes numerous barriers to conducting business (regulatory quality-RQ), it creates opportunities for rent seeking behaviour from public officials (COR). High quality regulation implies there are no excessive rules, and that rules are efficiency enhancing. Burden of government regulation, inefficiency of legal framework in settling disputes and inefficiency of legal framework in challenging regulations will all translate to higher implicit costs on MFI profitability. We therefore predict a positive relationship between quality regulatory practices and MFIs profitability. All of these factors are relevant to most African countries where the quality of institutions, is poor albeit with some disparities between the different economies (Creane et al, 2004).

\subsection{Model specification}

The empirical specification takes the following general form:

$\Pi_{i c t}=\alpha+\eta \Pi_{i c t-1}+\sum_{j=1}^{J} \beta_{j} \mathrm{X}_{i c t}^{j}+\sum_{n-1}^{N} \beta_{n} \mathrm{X}_{c t}^{n}+\sum_{m=1}^{M} \beta_{m} \mathrm{X}_{c t}^{m}+\varepsilon_{i c t}$

Where $\Pi_{i c t}$ is the profitability of MFI $i$ located in country $c$, at time $t$, with $\mathrm{i}=1, \ldots, \mathrm{N}, \mathrm{t}=1, \ldots, \mathrm{T}$; $\alpha$ is the regression constant, ${ }^{\mathrm{X}_{i c t}}$ is a vector of MFI-specific characteristics $(j)$ of MFI $i$ in country $c$ during the period $t$ which varies across time and MFIs; $\mathrm{X}_{c t}^{n}$ is a vector of institutions quality indicators $(n)$ in country $c$ during the period $t ; \mathrm{X}_{c t}^{m}$ is a vector of country-specific variables $(m)$ in country $c$ during the period $t$; and $\varepsilon_{i t c}=v_{i}+\mu_{i t c}$ is the disturbance, with $v_{i}$ the unobserved MFi-specific effect/heterogeneity across MFIs, which could be very large given the differences in corporate governance and $\mu_{i t c}$ the idiosyncratic error. $\Pi_{i c t-1}$ is the one-period lagged profitability and $\eta$ is the speed of adjustment to equilibrium. Thus, apart from state dependence $\left(\prod_{i c t-1}\right)$

4 This is particularly so if MFI is not domestic as domestic MFIs may be more willing to take on higher levels of risk because of moral hazard. Foreign MFIs may also run a higher risk of becoming a victim of violence.

5 Rule of law implies an open and transparent market, where contracts are enforced by a 'rule' that is publicly known to parties outside the contract and applied equitably no matter who the enforcer or the contract parties are. 
and observed heterogeneity $\left(\mathrm{X}_{i c t}^{j}, \mathrm{X}_{c t}^{n}\right.$ and $\mathrm{X}_{c t}^{m}$ ), the model also accounts for MFI-specific unobserved heterogeneity, and random idiosyncratic errors. This is a one-way error component regression model ${ }^{6}$, where $v_{i} \sim \operatorname{IIN}\left(0, \sigma_{v}^{2}\right)$ and independent of $\mu_{i t} \sim \operatorname{IIN}\left(0, \sigma_{\mu}^{2}\right)$.

Due to the significant differences that exist in the microfinance industry across Africa economies, we test for potential country effects. Additionally, it is possible that, within the twelve years time frame of the analysis, certain developments might have taken place in the microfinance industry and therefore time effects may be present in the error component of the model. We contend that failure to account for these two effects is likely to bias the study estimates. We test for country and time effects by including time and country specific dummies, respectively, in equation (3.1). The econometric model is therefore expanded as follows,

$$
\begin{aligned}
& \Pi_{i c t}=\alpha+\eta \Pi_{i c t-1}+\sum_{j=1}^{J} \beta_{j} \mathrm{X}_{i c t}^{j}+\sum_{n-1}^{N} \beta_{n} \mathrm{X}_{c t}^{n}+\sum_{m=1}^{M} \beta_{m} \mathrm{X}_{c t}^{m}+\delta D_{c-1}+\varepsilon_{i c} \\
& \varepsilon_{i c t}=v_{i}+\gamma_{t}+\mu_{i c t}
\end{aligned}
$$

Where, D denotes the country-specific dummy variables. $\varepsilon_{i c t}=v_{i}+\gamma_{t}+\mu_{i c t}$ is the disturbance; $\gamma_{t}$ is the unobservable time effects, ${ }^{v_{i}}$ is the unobserved complete set of MFI-specific effect and $\mu_{i c t}$ is the idiosyncratic error. The augmented model becomes an unbalanced two-way error component model. We test for country and time hypotheses separately as well as jointly, by H0: $\gamma_{2}=\gamma_{3}=\ldots \ldots=\gamma_{T}=0$ and present the results in Table A1 in the Appendix. We experimented with many country dummies and it turned out that none was significant. The Lagrange Multiplier (LM) tests show that for the microfinance industry in Africa, both country and time specific dummy variables are insignificant. We therefore should neither include year nor country specific dummies. Hence, we proceed with the estimation of model 3.1

\subsection{Interaction effects}

Microbanking is heavily dependent on personal contact for programs execution. Political stability may make it more conducive for young MFIs to form relationships with reliable new borrowers. In this case, the impact of political stability on deposits mobilization or growth of portfolio-assets ratio will decline with MFI age. Put differently, If young MFIs face high costs in identifying reliable borrowers, then the growth in portfolio-assets following a rise in political stability may outstrip their capacity to make new loans, in which case their loansassets ratio may fall, even if that of older MFIs is rising. This leads to a decline in MFI profitability. To this end we interact age with political stability (AgxPS).

The impact of corruption on MFI profitability may also vary with MFI age. Some older MFIs with ties to the political establishment may benefit from corruption, in so far as overcoming government bureaucracy is concerned. On this perspective, controlling corruption will increase older MFIs operational costs, but may benefit younger MFIs with weaker ties to the political establishment. Since new MFIs are likely to take away business from the more established MFIs, control of corruption may act as a deterrent to the growth of older MFIs. One would however expect that control of corruption would create a more level playing field which encourages the emergence and growth of new MFIs. We therefore interact corruption with age (CORxAg). Portfolio-assets ratio may also depend on control of corruption. Controlling corruption should encourage all MFIs to issue more loans. We thus interact corruption with portfolio-assets ratio (CORxPAsse).

The impact of rule of law (RL) on MFI profitability may also depend on the age of MFIs. Mature or older MFIs may have established relationship lending particularly those that employ joint liability contracts. Costly state verification may be more of a problem on young MFIs, who have less information capital to overcome the adverse selection effect. We thus interact age with rule of law (AgxRL).

\subsection{Definition and measurement of the variables}

Researchers use diverse definitions and measurements ${ }^{7}$ of institutions which include political instability, the attributes of political institutions, social characteristics and measures of the quality of institutions that affect economic exchange. Drawing from institutions theory, we use governance institutions to proxy country specific institutional environment. Institutional variables in most African countries are correlated with financial stability,

6 The work horse for unbalanced panel data applications is the one-way error component regression model (see Baltagi and Song 2006) 7 There are variations in the measurement of governance in the literature. One is a subjective measurement in which people's opinions about institutions are evaluated through a survey and then aggregated into a quantitative index. The alternative is an objective measurement based on statistical facts on the effects of institutions. For example, the wait time for obtaining government approval to start a business can be observed and used as a measurement for institutions. 
and therefore difficult to identify precisely (Demetriades and Fielding 2011). 'Good' institutions can sometimes have 'bad' outcomes, and very different institutional arrangements can lead to the same outcomes, making it very difficult to measure institutional quality (Dietsche 2007).

We analyze the impact of country specific institutional development on MFI profitability using WGI as compiled by Kaufmann, et al (2009) for the period 1997-2008. These include (i) Voice and Accountability (VA), (ii) Political Stability (PS), (iii) Government Effectiveness (GE), (iv) Regulatory Quality/ regulatory burden (RQ), (v) Rule of Law (RL) ${ }^{8}$ and (vi) Control of Corruption (COR). Studies that have used similar data include; Ahlin et al (2011), Demetriades and Fielding (2011), Cull et al (2011, 2009b), Arun and Annim (2010), Lensink et al (2008).

Voice and Accountability captures the extent of a free media, free and fair elections, freedom of expression and freedom of association. Political Stability (PS) proxies the possibility that a government will be overthrown by unconstitutional/violent means which includes domestic violence and terrorism. Government Effectiveness (GE) measures the quality of service delivery by the government which includes policy formulation and implementation, independence from political pressures and the credibility of the government's commitment to stated policies. Regulatory Quality (RQ) measures the ability of government to formulate and implement policies and regulations that are conducive to private sector investments. Rule of Law (RL) measures the agents' confidence levels in abiding by the rules of society particularly the criminal and commercial justice system. Finally, the measure of the extent to which a country is corruption-free is the "control of corruption" (COR) index.

Complementary business environment measures from Heritage foundation capture two aspects of institutional development. Business Freedom (BF) measures the ability to start, operate and close a business and represents the overall burden of regulation as well as the efficiency of government in the regulatory process. Business freedom is a composite index equivalent to the doing business indicators indices used by Ahlin et al (2011). Property rights (PR) is a composite Index ranging from 10 (private property is rarely protected) to 100 (private property is guaranteed by the government).

Most of the MFI specific control variables are the same as those used in previous studies (Muriu, 2012; Ahlin et al, 2011; Cull, et al, 2007; 2009b; 2011). Additional MFI-specific characteristics are captured by controls for share of lending to women. The regressions also include a number of country-level controls. The study considers two proxies for the macroeconomic environment; inflation and GDP per capita growth ${ }^{9}$. Further country-level controls include rural population share (in 1990). McIntosh, de Janvry and Sadoulet (2005) found that most of the microfinance entry in Uganda in the 1990s occurred in rural areas. On the contrary, Arun and Hulme, (2008) shows that MFIs mainly focus on the cities, towns and major rural trading centres. We therefore control for the possibility that rapidly growing rural areas may attract MFIs with a different profitability profile.

The regressions also include an additional set of country-level controls. The impact of competition by conventional retail banks on MFI profitability is measured by the ratio of amount of domestic credit to the private sector, divided by GDP. It is arguably the most common measure of financial development in the finance and growth literature, and it is included to proxy the overall financial depth of the country in which the MFI operates (see e.g. Levine, 2005). The level of financial deepening can either complement MFI profitability or crowd them out. Although McIntosh, de Janvry, and Sadoulet (2005) do not test whether entry into the MFIs activities by a conventional bank affects incumbents' profitability, they show that repayment rates declined in areas where entry was most pronounced, which should have a negative impact on MFI profitability. Competition should also depress MFI profits since they are likely to lose some of their better customers to conventional commercial banks. We thus expect a negative relationship between financial deepening and MFI profitability. We finally control for persistence of profitability.

Microfinance Financial Reporting Standards recommends the use of ROA and ROE as measures of MFI profitability rather than Operational Self-Sufficiency (OSS) and Financial Self-Sufficiency (FSS). We explore the impacts of country specific institutional measures on MFI profitability using return on assets (ROA) as the focal outcome. ROA is more appropriate since MFI equity in Africa is abnormally low (Lafourcade, et al 2006). It is also widely used in the literature, which allows comparison with previous studies. Debt/equity levels also differ considerably between MFIs. Hence, ROA is more appropriate than return on equity (ROE) when measuring financial performance across different institutions. The specific definition and source of all variables is presented in Table 1.

8 These aspects include: enforceability of private contracts, assessment of the strength and impartiality of the legal system, whether existing laws are actually implemented in a reliable and impartial fashion, quickness of court decisions, trust in police and courts, judicial independence from the state and other powerful groups, impact of crime on business, etc.

9 Ahlin et al (2011) use a similar measure. Demirgüc-Kunt and Huizinga (2000) used the annual growth rate of GDP and GNP per capita to identify such a relationship, while Bikker and $\mathrm{Hu}$ (2002) used a number of macroeconomic variables such as GDP, the unemployment rate and interest rate differentials. 
Table 1: Summary of variables, measurement and predicted effect

\begin{tabular}{|c|c|c|c|c|}
\hline Variable & Notation & Measure & $\begin{array}{l}\text { Predicted } \\
\text { effect }\end{array}$ & $\begin{array}{l}\text { Source of data } \\
\text { and period of } \\
\text { availability }\end{array}$ \\
\hline \multicolumn{5}{|c|}{ Dependent variable } \\
\hline Return on assets & ROA & Net profits after taxes/Assets & & $\begin{array}{l}\text { The MIX } \\
1997-2008\end{array}$ \\
\hline \multicolumn{5}{|c|}{ Institutional environment } \\
\hline \multicolumn{5}{|c|}{ Governance measures } \\
\hline $\begin{array}{l}\text { Voice and } \\
\text { Accountability }\end{array}$ & VA & $\begin{array}{l}\text { Measures the extent of political and } \\
\text { civil rights }\end{array}$ & Positive & \multirow{6}{*}{$\begin{array}{l}\text { WGI-World } \\
\text { Bank } \\
2008,2007,2006, \\
2005,2004, \\
2003,2002,2000, \\
1998\end{array}$} \\
\hline $\begin{array}{l}\text { Political } \\
\text { Stability }\end{array}$ & PS & $\begin{array}{l}\text { Measures the likelihood of violent } \\
\text { threats or changes in government }\end{array}$ & Positive & \\
\hline $\begin{array}{l}\text { Government } \\
\text { Effectiveness }\end{array}$ & GE & $\begin{array}{l}\text { An indicator of the competence and the } \\
\text { quality of public service delivery }\end{array}$ & Positive & \\
\hline $\begin{array}{l}\text { Regulatory } \\
\text { Quality }\end{array}$ & RQ & $\begin{array}{l}\text { Measures the incidence of market- } \\
\text { friendly policies }\end{array}$ & Positive & \\
\hline Rule of Law & RL & $\begin{array}{l}\text { A proxy for the quality of contract } \\
\text { enforcement, the police and the courts, } \\
\text { as well as the likelihood of crime and } \\
\text { violence }\end{array}$ & Positive & \\
\hline $\begin{array}{l}\text { Control of } \\
\text { Corruption }\end{array}$ & COR & $\begin{array}{l}\text { Measures the exercise of public power } \\
\text { for private gain, including both soft and } \\
\text { grand corruption and state capture }\end{array}$ & Positive & \\
\hline \multicolumn{5}{|c|}{ Other complementary business environment measures } \\
\hline $\begin{array}{l}\text { Business } \\
\text { freedom }\end{array}$ & $\mathrm{BF}$ & $\begin{array}{l}\text { The score is based on } 10 \text { factors, all } \\
\text { weighted equally, using data from the } \\
\text { World Bank's Doing Business } \\
\text { Indicators (2010) }\end{array}$ & Positive & \multirow[t]{2}{*}{$\begin{array}{l}\text { Heritage } \\
\text { Foundation } \\
1997-2008\end{array}$} \\
\hline Property rights & PR & $\begin{array}{l}\text { Composite Index ranging from } 10 \\
\text { (Private property is rarely protected) to } \\
100 \text { (Private property is guaranteed by } \\
\text { the government) }\end{array}$ & Positive & \\
\hline \multicolumn{5}{|c|}{ MFI-specific variables } \\
\hline Capital & CAP & Equity/Assets & Positive & \multirow{10}{*}{$\begin{array}{l}\text { The MIX } \\
1997-2008\end{array}$} \\
\hline $\begin{array}{l}\text { Debt to equity } \\
\text { (gearing) ratio }\end{array}$ & GR & Debt/equity ratio & Indeterminate & \\
\hline $\begin{array}{l}\text { Deposits to } \\
\text { assets }\end{array}$ & DepAsse & $\begin{array}{l}\text { Voluntary Deposits/Adjusted Gross } \\
\text { Loan Portfolio }\end{array}$ & Positive & \\
\hline $\begin{array}{l}\text { Portfolio to } \\
\text { assets }\end{array}$ & PAsset & $\begin{array}{lll}\text { Adjusted } & \text { Gross } & \text { Loan } \\
\text { Portfolio/Adjusted Total Assets } & \end{array}$ & Positive & \\
\hline Age & $\mathrm{Ag}$ & Log of age of the MFI in years & Indeterminate & \\
\hline MFI Size & $\mathrm{S}$ & Log of total assets in period $t$ & Indeterminate & \\
\hline Portfolio at Risk & PAR-30 & 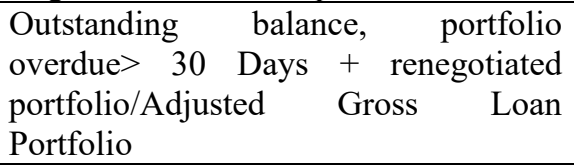 & Negative & \\
\hline Efficiency & Eff & $\begin{array}{l}\text { Adjusted Operating Expense/Adjusted } \\
\text { Average Gross Loan Portfolio }\end{array}$ & Negative & \\
\hline Loan size & $\mathrm{LS}$ & $\begin{array}{l}\text { Average Loan } \\
\begin{array}{l}\text { Balance per } \\
\text { Borrower/GNI per Capita (outreach } \\
\text { measure) }\end{array}\end{array}$ & Positive & \\
\hline $\begin{array}{l}\text { Share of lending } \\
\text { to women }\end{array}$ & WOM & $\begin{array}{l}\text { Share of MFI borrowers that are } \\
\text { women }\end{array}$ & Positive & \\
\hline \multicolumn{5}{|c|}{ Country specific variables } \\
\hline $\begin{array}{l}\text { Inflation } \\
\text { Expectations }\end{array}$ & INF & $\begin{array}{l}\text { Inflation, consumer prices (annual \%) } \\
\text { in period } t-1\end{array}$ & Indeterminate & $\begin{array}{l}\text { World } \\
\text { (WDI) }\end{array}$ \\
\hline
\end{tabular}




\begin{tabular}{|l|l|l|l|l|}
\hline $\begin{array}{l}\text { Per capita } \\
\text { Income growth }\end{array}$ & GDP & $\begin{array}{l}\text { Gross Domestic Product (at current } \\
\text { US\$) divided by midyear population in } \\
\text { period } t-1\end{array}$ & Positive & 1997-2008 \\
\hline $\begin{array}{l}\text { Domestic credit } \\
\text { to private sector }\end{array}$ & PCRED & $\begin{array}{l}\text { Domestic credit to the private sector, } \\
\text { divided by GDP. }\end{array}$ & Indeterminate \\
\cline { 1 - 1 } $\begin{array}{l}\text { Rural } \\
\text { population (\%) }\end{array}$ & RPOP & Rural population share (in 1990) & Negative & \\
\hline
\end{tabular}

\subsection{Estimation and testing}

MFI profitability is predicted in linear regressions by the institutional context indicators, country and MFI-level control variables. Given the nature of the data, we focus on estimation approaches that are robust to outliers. When estimating equation (3.1), we are likely to encounter several econometric problems. First is endogeneity: If it's possible that good institutions drive MFI profitability, it is also possible that countries that experience sustained growth in microfinance profitability are also likely to offer well-developed institutions. We observe that due to this endogeneity, these regressors may be correlated with the error term.

Second, because of the subjective nature of institutional quality measurement, one cannot exclude the possibility of measurement errors in the various indices which may bias the results. Third, countries endowed with good institutions can also have other factors favourable for microfinance profitability, the omission of which exacerbates endogeneity. There may be other factors, such as geography, that affect both institutions and MFI profitability. If omitted factors determine both institutions development and MFI profitability, one could erroneously infer the existence of a relationship between them.

Because of the endogeneity of institutions, the OLS estimation is biased ${ }^{10}$. Obtaining a consistent estimator calls for the use of an instrumental variable for country specific institutions. Since most instrumental variables for institutions are constant over time, we do not have suitable instruments to correct for endogeneity. We resolve these problems by moving beyond the methodology currently in use in the empirical literature (mainly fixed or random effects). We use system GMM method of Blundell and Bond (1998) which allows us to use internal instruments; namely, lagged levels and lagged differences.

MFIs profitability outcome may be highly persistent so the lagged levels might be very weak instruments for the first differenced equations. In this situation, the first-differenced GMM estimator potentially suffers from a downward bias (Blundell and Bond, 1998). Thus the additional set of first-differenced instruments and equations in levels make the system GMM estimator more efficient by overcoming the weak instrument problem inherent to the first-differenced GMM estimator. We instrument for all regressors except for those which are clearly exogenous.

The last challenge is the risk of omitted variables. To that end, we follow a general to specific strategy by estimating an equation with all possible regressors according to the existing literature. Finally, to confirm the validity of the instruments, we perform Hansen's or Sargan test of over-identifying restrictions, which is asymptotically distributed as $\chi^{2}(k)$ where $k$ denotes the number of over-identifying restrictions. We also test whether Arellano-Bond orthogonality conditions are fulfilled.

\subsection{Data}

The data sample contains 2,004 observations corresponding to 167 MFIs for the period 1997-2008. The dataset was assembled from four sources namely the MIX Market database, World Development Indicators (WDI) and World Bank-World Governance Indicators ${ }^{11}$ (WGI). We also used complementary institutional data from the Heritage Foundation. ${ }^{12}$ Economic performance control variables are per capita GDP growth and private credit as a fraction of GDP. Auxiliary indicators, include inflation and rural population share (in 1990). These were obtained from WDI. We merge the MFI level dataset with country-level data from WDI on macroeconomic variables and institutional development indices from WGI, for each of the countries and years corresponding to MFI's in the dataset. The WGI aggregate indicators for all periods, as well as virtually all of the underlying indicators, are described and discussed in Kaufmann et al. (2009) and available at www.govindicators.org. For some years (1997,1999 and 2001) data is missing. Consistent with Lensink et al. (2008), the study proxies values for the missing years by interpolating the data.

10 The estimation methods based on the OLS principle are vulnerable to the omitted variable bias if some important determinants of MFI profitability are not included among the regressors.

11 Governance can be broadly defined as the process by which governments are selected, monitored and replaced, the capacity of the government to effectively formulate and implement sound policies, and the respect of citizens and the state for the institutions that govern economic and social interactions among them (Kaufmann, et al 2009)

12 http://www.heritage.org/index/ 


\section{Empirical findings and discussion}

\subsection{Descriptive statistics}

Table 2 shows summary statistics. The minimum values are a clear indication that governance is negatively skewed, which may impede on MFIs performance. Negative means in the sample indicate that Africa economies perform below the worldwide average in terms of institutional quality. It is a matter of considerable concern that governance institutions in Africa are on average quite weak. This is consistent with studies that have found strong positive effect of governance on development (See e.g. Ritzen et al., 2000; Kaufman and Kraay, 2002).

Table 2: Descriptive and summary statistics

\begin{tabular}{|c|c|c|c|c|c|c|c|}
\hline Variable & Notation & Obs & Mean & Median & $\begin{array}{l}\text { Standard } \\
\text { Deviation }\end{array}$ & Minimum & Maximum \\
\hline Return on assets & $\mathrm{ROA}$ & 946 & -0.016 & 0.007 & 0.121 & -0.851 & 0.830 \\
\hline Log Age & $\mathrm{AG}$ & 945 & 2.180 & 2.197 & 0.607 & 0 & 3.7 \\
\hline Log Size & $\mathrm{S}$ & 947 & 15.02 & 14.79 & 1.821 & 7.86 & 20.71 \\
\hline Efficiency & EFF & 914 & 0.379 & 0.294 & 0.285 & 0.025 & 1.92 \\
\hline Portfolio at Risk & PAR & 937 & 0.066 & 0.037 & 0.093 & 0 & 0.737 \\
\hline Capital & CAP & 945 & 0.369 & 0.307 & 0.279 & -0.983 & 1.000 \\
\hline $\begin{array}{l}\text { Debt to equity ratio } \\
\text { (gearing) }\end{array}$ & GR & 844 & 0.257 & 1.602 & 1.348 & -6.215 & 3.218 \\
\hline Deposits to assets ratio & DepAsse & 382 & 0.386 & 0.329 & 0.255 & 0.000 & 0.960 \\
\hline Portfolio to assets & PAsset & 805 & 0.659 & 0.673 & 0.173 & 0.057 & 0.990 \\
\hline Loan size & LS & 847 & 0.790 & 0.569 & 0.709 & 0.000 & 3.541 \\
\hline Share of lending to women & WOM & 764 & 0.604 & 0.615 & 0.260 & 0.000 & 1.000 \\
\hline Rural population share & RPOP & 950 & 0.687 & 0.684 & 0.132 & 0.390 & 0.910 \\
\hline GDP Per capita & GDP & 784 & 0.998 & 2.837 & 0.845 & -2.43 & 2.37 \\
\hline Lagged Inflation rate & INF & 951 & 0.672 & 0.062 & 0.063 & -0.090 & 0.431 \\
\hline $\begin{array}{l}\text { Domestic credit to private } \\
\text { sector }\end{array}$ & PCRED & 959 & 0.1347 & 0.1306 & 0.0768 & 0.000 & 0.442 \\
\hline Voice and Accountability & VA & 963 & -0.454 & -0.385 & 0.619 & -1.766 & 0.846 \\
\hline Political Stability & PS & 963 & -0.666 & -0.408 & 0.823 & -2.638 & 0.712 \\
\hline Government Effectiveness & GE & 963 & -0.649 & -0.584 & 0.429 & -1.893 & 0.951 \\
\hline Regulatory Quality & RQ & 963 & -0.539 & -0.444 & 0.431 & -2.369 & 0.635 \\
\hline Rule of Law & RL & 963 & -0.686 & -0.616 & 0.424 & -1.897 & 0.242 \\
\hline Control of Corruption & COR & 963 & -0.668 & -0.717 & 0.406 & -1.576 & 0.595 \\
\hline Business freedom & $\mathrm{BF}$ & 806 & 55.25 & 55.0 & 5.33 & 32 & 67.1 \\
\hline Property rights & PR & 806 & 37.78 & 30.0 & 11.28 & 10 & 70.0 \\
\hline
\end{tabular}

This Table presents the summary statistics. A detailed description of the definition and sources of the variables is given in Table 1. Data has been winsorized at $10 \%$

\subsection{Correlation analysis}

The institutional variables show very high and significant bivariate correlations (see Table 3). This correlation may be due to a causal impact from one variable to another (in either direction) as discussed in section 3.1, or it may reflect the effect of some unobserved confounding factor such as "good government". Licht et al. (2007), for instance show that some aspects of 'national culture' affect COR, RL and VA. Roe and Siegel (2011), Damania et al. (2004) show that political instability impairs rule of law, in turn stimulating corruption. Alence (2004) finds that democratic contestation and executive restraints affect RQ, GE and COR. This perhaps explains the high correlations among the institutional variables and therefore good governance correlates with positive development outcomes. Correlations among MFI specific variables are significant but the level of correlation is very low. The bi-variate relationships follow expectations based on the existing literature that uses this or similar data (See Cull et al 2009c). The multicollinearity between these governance indicators precludes the inclusion of more than one of these variables in the regression equation. We thus fit a series of regressions, each with a single variable of these governance indicators. 
Table 3 Correlations matrix

\begin{tabular}{|c|c|c|c|c|c|c|c|c|c|c|c|c|c|c|c|c|c|c|c|c|c|c|c|}
\hline 8 & ROA & DepAsse & \begin{tabular}{|l|l|} 
PAsse \\
\end{tabular} & GR & $\begin{array}{l}\text { CAP } \\
\end{array}$ & $\mathrm{AG}$ & $\mathrm{s}$ & EFF & $\begin{array}{l}\text { PAR } \\
\end{array}$ & LS & WOM & \begin{tabular}{l|l|l|} 
RPOP \\
\end{tabular} & GDP & INFF & PCRED & $\mathrm{VA}$ & $\begin{array}{l}\text { PS } \\
\end{array}$ & GEF & $R Q$ & $\mathrm{RL}$ & $\mathrm{COR}$ & \begin{tabular}{|l|} 
BUSF \\
\end{tabular} & PR \\
\hline $\mathrm{ROA}$ & 1.000 & & & & & & & & & & & & & & & & & & & & & & \\
\hline DepAsse & .066 & 1.000 & & & & & & & & & & & & & & & & & & & & & \\
\hline $\begin{array}{l}\text { PAsse } \\
\end{array}$ & |.65 & .012 & $\mid 1.000$ & & & & & & & & & & & & & & & & & & & & \\
\hline GR & . $172^{2 * *}$ & $339^{* *}$ & 001 & 1.000 & & & & & & & & & & & & & & & & & & & \\
\hline CAP & $.101^{* *}$ & $.541^{* *}$ & 0.21 & $-367^{* *}$ & 1.000 & & & & & & & & & & & & & & & & & & \\
\hline$\overline{A G}$ & $142^{* * *}$ & $.254^{* *}$ & .002 & $110^{* * *}$ & $-204^{* *}$ & 1.000 & & & & & & & & & & & & & & & & & \\
\hline $\mathrm{s}$ & $1111^{* *}$ & $.213^{* *}$ & .030 & $124^{* *}$ & $-.142^{* * *}$ & 351 & $\mid 1.000$ & & & & & & & & & & & & & & & & \\
\hline EFF & $.524^{* * *}$ & $.189 * *$ & $.075^{*}$ & $.130^{* *}$ & $216^{* *}$ & -.190** & $.086^{* *}$ & 1.000 & & & & & & & & & & & & & & & \\
\hline \begin{tabular}{|l|l} 
PAR \\
\end{tabular} & .046 & $209^{* *}$ & .004 & $101^{* *}$ & $\begin{array}{l}.062 \\
\end{array}$ & \begin{tabular}{|l|}
.056 \\
\end{tabular} & \begin{tabular}{|c|}
.007 \\
\end{tabular} & $\mid 019^{*}$ & 1.000 & & & & & & & & & & & & & & \\
\hline LS & . $178^{* * *}$ & $322^{* *}$ & 102 & .058 & -.242 & $.052^{*}$ & $133^{* *}$ & $.198^{* *}$ & $-.002^{* *}$ & 1.000 & & & & & & & & & & & & & \\
\hline WOM & $.179^{* * *}$ & $-415^{* *}$ & $112^{* * *}$ & . $.154^{* *}$ & $201^{* *}$ & -.094 & .149 & 273 & .084 & -309 & 1.000 & & & & & & & & & & & & \\
\hline RPOP & .072 & $-156^{* *}$ & .028 & $.097^{* *}$ & $.099^{* *}$ & $\mid-094 * *$ & .011 & .046 & $.078^{*}$ & .063 & $.081^{*}$ & 1.000 & & & & & & & & & & & \\
\hline GDP & .035 & $-266^{* *}$ & 036 & $.070^{*}$ & $132^{* *}$ & $.090^{* *}$ & .003 & .139** & $.088^{* *}$ & -.016 & .016 & $254^{* * *}$ & 1.000 & & & & & & & & & & \\
\hline INF & 011 & $-119^{*}$ & .004 & .017 & $130^{* *}$ & .052 & .052 & $227^{* *}$ & $102^{* *}$ & $-.120^{* *}$ & $197^{* *}$ & $\mid .081^{* *}$ & $294^{* * *}$ & 1.000 & & & & & & & & & \\
\hline $\begin{array}{l}\text { PCRED } \\
\end{array}$ & $\mid .050$ & .002 & .062 & .006 & $-.125^{* *}$ & $1112^{* *}$ & $106^{* *}$ & $.210^{* *}$ & .023 & -.027 & .012 & $\mid 271^{* * *}$ & .003 & $.148^{* *}$ & 1.000 & & & & & & & & \\
\hline $\mathrm{VA}$ & .011 & .098 & .052 & .012 & $\begin{array}{l}-.018 \\
\end{array}$ & $152^{* *}$ & $1116^{* *}$ & \begin{tabular}{|l|}
.058 \\
\end{tabular} & $-0.067^{*}$ & .006 & $\mid .079^{*}$ & $.328^{*}$ & $.076^{*}$ & -.001 & .061 & 1.000 & & & & & & & \\
\hline PS & $\mid .054$ & .077 & 026 & .028 & .003 & .022 & .006 & .019 & $.085^{* * *}$ & $.170^{* *}$ & .036 & $.210^{* *}$ & $-.143^{* *}$ & -.039 & $.131^{* *}$ & 683** & 1.000 & & & & & & \\
\hline GEF & .000 & .003 & \begin{tabular}{|l|}
.029 \\
\end{tabular} & .038 & $.079^{* *}$ & .033 & $157^{* *}$ & $\mid .090^{* *}$ & $-.145^{* *}$ & -014 & .020 & $\mid .092^{* * *}$ & \begin{tabular}{|l|l}
$140^{* *}$ \\
\end{tabular} & .038 & $.196^{* *}$ & $7708^{* *}$ & $535^{* * *}$ & 1.000 & & & & & \\
\hline RQ & 011 & $184^{* *}$ & .015 & 010 & $-.070^{*}$ & $175^{* *}$ & $184 * *$ & .063 & $.124^{* * *}$ & .050 & .012 & .049 & $.071 * *$ & $-.076^{* *}$ & . $194^{* * *}$ & $.706^{* *}$ & $492^{* *}$ & $771^{* * *}$ & 1.000 & & & & \\
\hline RL & .025 & .020 & 012 & .060 & 019 & .015 & .058 & .006 & $.145^{* * *}$ & $1.086^{* *}$ & .067 & .038 & $.065^{* *}$ & -046 & $.116^{* *}$ & $707 * *$ & $691 * *$ & $815^{* * *}$ & $730^{* *}$ & 1.000 & & & \\
\hline COR & .026 & $.101^{* *}$ & \begin{tabular}{|l|}
.045 \\
\end{tabular} & .020 & 015 & .027 & $\mid 063^{* * *}$ & .007 & $.095^{* *}$ & $.125^{* *}$ & $.106^{* *}$ & $.120^{* * *}$ & .022 & $.071^{*}$ & $-210^{* *}$ & $.588^{* *}$ & 615** & $756^{* *}$ & $.627^{* * *}$ & $.849^{* *}$ & 1.000 & & \\
\hline BUSF & .007 & -.037 & $\mid .033$ & $.114^{*}$ & $167^{* *}$ & .050 & $.099 * *$ & $120^{* * *}$ & $\mid-019$ & .027 & .032 & $149^{* *}$ & $168^{* *}$ & .034 & .006 & $242^{* *}$ & 0.050 & $402^{* *}$ & $299^{* *}$ & $317^{* *}$ & $.245^{* *}$ & 1.000 & \\
\hline PR & .000 & .082 & .036 & $.092^{* * *}$ & $.115^{* *}$ & .033 & $\mid 078^{*}$ & $102^{* *}$ & -.028 & .027 & 049 & $107 * *$ & .027 & .048 & $.091^{* *}$ & $369^{* *}$ & $195^{* *}$ & $496^{* *}$ & $575^{* *}$ & $477^{* * *}$ & $386^{* *}$ & $.510^{* *}$ & 1.00 \\
\hline
\end{tabular}

**Correlation is significant at the 0.01 level (2-tailed). ${ }^{*}$ Correlation is significant at the 0.05 level (2-tailed). Where ROA=Return on Assets; $\mathrm{AG}=$ Age of the MFI; $\mathrm{S}=$ Size; CAP=Capital; $\mathrm{GR}=\mathrm{Gearing}$; DepAsse=Deposit to Assets ratio; $\mathrm{EFF}=$ Efficiency; $\mathrm{PAR}=$ Portfolio at Risk; WOM=Share of lending to women; RPOP=Rural population share; INF=Lagged Inflation; GDP= Growth of per capita income; PCRED=Domestic credit to private sector; VA=Voice and Accountability; PS=Political Stability; GE=Government Effectiveness; $\mathrm{RQ}=$ Regulatory Quality; $\mathrm{RL}=$ Rule of Law; Control of Corruption; $\mathrm{BF}=$ Business freedom; $\mathrm{PR}=$ Property rights

\subsection{Estimation results}

Table 4 presents the estimation results. It is important to note that the robustness of system GMM to omitted variable bias helps us in this setting, since exclusion of some insignificant variables does not affect the consistency of the results. The hypothesis of over identifying restrictions can't be rejected based on the Sargantest. The Arellano-Bond test for serial correlation in the first-differenced residuals is not significant in all specifications supporting the appropriateness of the empirical specification

The results suggest that institutional environment matters for MFI profitability. Political stability, government effectiveness, rule of law, regulatory quality and corruption are quantitatively strong predictors of microfinance profitability. On average, MFIs are more profitable when there is political stability. Perhaps in more stable environments there is higher demand for credit, which is channelled to higher-growth activities. This effect is however sensitive to MFI age. Younger MFIs are most affected, suggesting that they face the most severe informational disadvantages. This may affect the extent of moral hazard that they face when advancing loans. The findings complements Anayiotos and Toroyan (2009), who finds that political stability determines financial inclusion in many Africa economies.

The estimation results reveals a statistically significant positive coefficient on the rule of law variable and a statistically significant negative coefficient on the interaction term AG·RL. Results are consistent with the conjecture that young MFIs face high costs in contract enforcement and costly state verification. Intuitively young MFIs may not have accumulated enough information capital to overcome the adverse selection effect. Consistent with this finding, Behr, et al (2011) show that relationship intensity between MFIs and their borrowers helps to overcome existing information asymmetries. Access to credit improves and that the loan approval process takes less time. Institutions promoting rule of law may therefore enhance MFIs' ability to enforce loan contracts and hence profitability.

Results also suggest that government effectiveness may reduce the costs of doing business for both MFIs and micro-borrowers. Indeed the Global Competitiveness Report 2009-2010 points to government inefficiency as the worst obstacle for doing business within Africa economies. Study findings suggest that corruption may make it harder for MFIs to upscale their performance. Moreover, growth of loan portfolio may be slower where 
there is more corruption. This is consistent with the theoretical postulation that corruption is a barrier to microenterprise activities (Fisman and Svensson 2007). This has implications on MFIs profitability since microenterprises are the main clients of MFIs. Intuitively, high corruption taxes micro-enterprise operations and creates barriers to their expansion, reducing demand for microloans. Corruption may therefore reduce the probability that MFI will invest in a country.

The positive coefficient of regulatory quality is an indication that a lighter burden on regulation, efficiency in settling commercial disputes may all translate to lower implicit costs on MFI operations with improved profitability. This would be consistent with arguments that favour relaxed regulations for MFIs. The conjecture that a higher level of voice and accountability may enhance MFIs performance is not supported here. Contrary to Hartarska and Nadolnyak, (2007), we do not find evidence that business environment and property rights influence profitability perhaps due to low variability of data.

Overall, the study findings are not consistent with Ahlin et al (2011), Arun and Annim (2010) Cull et al (2009b). One major shortcoming with these previous studies is that they do not attempt to control for endogeneity. Though unrelated to this paper, our findings complements Hallward-Driemeier (2009) who concludes that inefficiency of government services, endemic corruption, regulatory burdens, less developed financial and legal institutions all raise the probability that more productive firms exit. It is however, far from a fore-drawn conclusion that what holds true for the corporate firms as a whole will also hold true for MFI's.

Estimations on the control variables shows that apart from credit risk and managerial inefficiency, average profitability is higher for large MFIs with high leverage, highly capitalized and those that mobilize deposits. The study hypothesis that competition from retail banks reduces the profits of MFIs is not supported here. This finding is consistent with Ahlin et al (2011), who finds no empirical support that financial deepening enhances MFIs self-sufficiency. Cull et al (2009b), similarly finds no significant evidence that greater bank penetration in the overall economy is associated with lower microfinance profitability ${ }^{13}$. This suggests that conventional banks' motivation to roll out branch networks is perhaps made independent of the presence and activities of MFIs.

Table 4: The impact of institutions of the host country on profitability (including Interaction terms)

\begin{tabular}{|c|c|c|c|c|c|c|}
\hline \multirow[t]{2}{*}{ Variable } & \multicolumn{6}{|c|}{ Variant of model specifications } \\
\hline & 1 & 2 & 3 & 4 & 5 & 6 \\
\hline Lagged ROA & $\begin{array}{l}0.2300^{* * *} \\
(2.49)\end{array}$ & $\begin{array}{l}0.2050^{* *} \\
(2.22)\end{array}$ & $\begin{array}{l}0.2089^{* * * *} \\
(2.59)\end{array}$ & $\begin{array}{l}0.1972 * * \\
(2.11)\end{array}$ & $\begin{array}{c}0.1798^{* *} \\
(2.04)\end{array}$ & $\begin{array}{l}0.1711^{* *} \\
(1.99)\end{array}$ \\
\hline Log Age & $\begin{array}{l}-0.0036 \\
(-1.38) \\
\end{array}$ & $\begin{array}{r}-0.0039 \\
(-1.35) \\
\end{array}$ & $\begin{array}{l}-0.0033 \\
(-1.24) \\
\end{array}$ & $\begin{array}{l}-0.0033 \\
(-1.27) \\
\end{array}$ & $\begin{array}{r}-0.0036 \\
(-1.34) \\
\end{array}$ & $\begin{array}{r}-0.0035 \\
(-1.28) \\
\end{array}$ \\
\hline Log size & $\begin{array}{l}0.0354 * * * \\
(2.64)\end{array}$ & $\begin{array}{l}0.0304 * * * \\
(2.32)\end{array}$ & $\begin{array}{l}0.0394 * * * \\
(3.04)\end{array}$ & $\begin{array}{l}0.0342 * * * \\
(2.61)\end{array}$ & $\begin{array}{l}0.0364 * * * \\
(2.84)\end{array}$ & $\begin{array}{l}0.0390 * * * \\
(2.99)\end{array}$ \\
\hline Capital & $\begin{array}{l}0.2404 * * * \\
(5.53)\end{array}$ & $\begin{array}{l}0.2171^{* * * *} \\
(5.00)\end{array}$ & $\begin{array}{l}0.2365^{* * * *} \\
(5.63)\end{array}$ & $\begin{array}{l}0.2443 * * * \\
(5.75)\end{array}$ & $\begin{array}{l}0.2262 * * * \\
(5.35)\end{array}$ & $\begin{array}{l}0.2309^{* * *} \\
(5.38)\end{array}$ \\
\hline Gearing & $\begin{array}{l}0.0076^{* * *} \\
(3.72)\end{array}$ & $\begin{array}{l}0.0058^{* * * *} \\
(3.89)\end{array}$ & $\begin{array}{l}0.0074 * * * \\
(3.53)\end{array}$ & $\begin{array}{l}0.0078^{* * *} \\
(3.70)\end{array}$ & $\begin{array}{l}0.0072 * * * \\
(3.40)\end{array}$ & $\begin{array}{l}0.0079^{* * *} \\
(3.69)\end{array}$ \\
\hline Deposit/Asset & $\begin{array}{l}0.3168^{* * *} \\
(3.91)\end{array}$ & $\begin{array}{l}0.2580 * * * \\
(3.29)\end{array}$ & $\begin{array}{l}0.2876^{* * * *} \\
(3.86)\end{array}$ & $\begin{array}{l}0.2788^{* * *} \\
(3.56)\end{array}$ & $\begin{array}{l}0.2497 * * * \\
(3.22)\end{array}$ & $\begin{array}{l}0.2931 * * * \\
(3.89)\end{array}$ \\
\hline Portfolio/Asset & $\begin{array}{l}0.0642 * * * \\
(3.41)\end{array}$ & $\begin{array}{l}0.0611 * * * \\
(3.34)\end{array}$ & $\begin{array}{l}0.0634 * * * \\
(3.17)\end{array}$ & $\begin{array}{l}0.0642 * * * \\
(3.25)\end{array}$ & $\begin{array}{l}0.0624 * * * \\
(3.31)\end{array}$ & $\begin{array}{l}0.0671 * * * \\
(3.14)\end{array}$ \\
\hline Efficiency & $\begin{array}{l}-0.3003 * * * \\
(-3.95)\end{array}$ & $\begin{array}{c}-0.3475^{* * *} \\
(-5.41)\end{array}$ & $\begin{array}{c}-0.3145^{* * *} \\
(-5.24)\end{array}$ & $\begin{array}{l}-0.3098 * * * \\
(-5.06)\end{array}$ & $\begin{array}{l}-0.3166^{* * *} \\
(-5.28)\end{array}$ & $\begin{array}{l}-0.3103 * * * \\
(-5.10)\end{array}$ \\
\hline Portfolio at risk & $\begin{array}{l}-0.2404 * * * \\
(-2.42)\end{array}$ & $\begin{array}{c}-0.2386^{* * * *} \\
(-2.47)\end{array}$ & $\begin{array}{l}-0.1918^{* *} \\
(-1.93)\end{array}$ & $\begin{array}{l}-0.2356 * * * \\
(-2.41)\end{array}$ & $\begin{array}{l}-0.1865^{* *} \\
(-1.88)\end{array}$ & $\begin{array}{l}-0.1905^{* *} \\
(1.87)\end{array}$ \\
\hline Loan Size & $\begin{array}{l}-0.0182 \\
(-0.85) \\
\end{array}$ & $\begin{array}{l}-0.0234 \\
(-1.11) \\
\end{array}$ & $\begin{array}{l}-0.0218 \\
(-1.04) \\
\end{array}$ & $\begin{array}{l}-0.0228 \\
(-1.07) \\
\end{array}$ & $\begin{array}{l}-0.0180 \\
(-0.86)\end{array}$ & $\begin{array}{l}-0.0241 \\
(-1.13) \\
\end{array}$ \\
\hline Women & $\begin{array}{l}-0.0211 \\
(-0.44) \\
\end{array}$ & $\begin{array}{l}-0.0023 \\
-0.05) \\
\end{array}$ & $\begin{array}{l}-0.0103 \\
(-0.22) \\
\end{array}$ & $\begin{array}{l}-0.0111 \\
(-0.23) \\
\end{array}$ & $\begin{array}{l}-0.0061 \\
(-0.13)\end{array}$ & $\begin{array}{l}-0.0096 \\
(-0.20)\end{array}$ \\
\hline $\begin{array}{l}\text { Voice and } \\
\text { Accountability }\end{array}$ & $0.0053 \quad(0.14)$ & & & & & \\
\hline Political Stability & & $\begin{array}{l}0.0550 * * * \\
(2.27)\end{array}$ & & & & \\
\hline PSXAge & & $\begin{array}{l}-0.0009 * * * \\
(-5.14)\end{array}$ & & & & \\
\hline $\begin{array}{l}\text { Government } \\
\text { Effectiveness }\end{array}$ & & & $\begin{array}{l}0.0746 * * \\
(2.22)\end{array}$ & & & \\
\hline $\begin{array}{l}\text { Regulatory } \\
\text { Quality }\end{array}$ & & & & $\begin{array}{l}0.0601^{*} \\
(1.81)\end{array}$ & & \\
\hline Rule of Law & & & & & $\begin{array}{l}0.0821 * * * \\
(2.35)\end{array}$ & \\
\hline RLXAge & & & & & $\begin{array}{l}-0.0159 * * * \\
(-5.29)\end{array}$ & \\
\hline
\end{tabular}

13 Their findings indicate that the standard measures of financial development (private credit/GDP), are statistically significant in only one of twelve possible cases. 


\begin{tabular}{|c|c|c|c|c|c|c|}
\hline \multirow[t]{2}{*}{ Variable } & \multicolumn{6}{|c|}{ Variant of model specifications } \\
\hline & 1 & 2 & 3 & 4 & 5 & 6 \\
\hline $\begin{array}{l}\text { Control of } \\
\text { Corruption }\end{array}$ & & & & & & $\begin{array}{c}-0.0290^{* *} \\
(-2.29)\end{array}$ \\
\hline CORXAge & & & & & & $\begin{array}{l}0.0044 \\
(1.51) \\
\end{array}$ \\
\hline $\begin{array}{l}\text { CORXPortfolio- } \\
\text { assets ratio }\end{array}$ & & & & & & $\begin{array}{l}-0.0424 * * * \\
(2.83)\end{array}$ \\
\hline $\begin{array}{l}\text { Business } \\
\text { Freedom }\end{array}$ & $\begin{array}{l}-0.0002 \\
(-0.27) \\
\end{array}$ & $\begin{array}{l}-0.00002 \\
(-0.03)\end{array}$ & $\begin{array}{l}-0.0005 \\
(-0.66)\end{array}$ & $\begin{array}{l}0.00001 \\
(0.02)\end{array}$ & $\begin{array}{l}-0.0003 \\
(-0.35) \\
\end{array}$ & $\begin{array}{l}0.0001 \\
(0.06)\end{array}$ \\
\hline Property Rights & $\begin{array}{l}0.0006 \\
(0.45) \\
\end{array}$ & $\begin{array}{l}0.0004 \\
(0.31) \\
\end{array}$ & $\begin{array}{l}0.0005 \\
(0.41) \\
\end{array}$ & $\begin{array}{l}0.0004 \\
(0.31) \\
\end{array}$ & $\begin{array}{l}0.0006 \\
(0.48) \\
\end{array}$ & $\begin{array}{l}0.0003 \\
(0.22)\end{array}$ \\
\hline $\begin{array}{l}\text { Share of rural } \\
\text { population }\end{array}$ & $\begin{array}{r}-0.0055 \\
(-0.52) \\
\end{array}$ & $\begin{array}{l}-0.0047 \\
(-0.63) \\
\end{array}$ & $\begin{array}{l}-0.0048 \\
(-0.61) \\
\end{array}$ & $\begin{array}{l}-0.0040 \\
(-0.62) \\
\end{array}$ & $\begin{array}{l}-0.0036 \\
(-0.69) \\
\end{array}$ & $\begin{array}{l}-0.0044 \\
(-0.66) \\
\end{array}$ \\
\hline $\begin{array}{l}\text { Inflation } \\
\text { expectations }\end{array}$ & $\begin{array}{r}0.0741 \\
(0.78) \\
\end{array}$ & $\begin{array}{l}0.1040 \\
(1.15) \\
\end{array}$ & $\begin{array}{l}0.0591 \\
(0.66) \\
\end{array}$ & $\begin{array}{r}0.1285 \\
(1.32) \\
\end{array}$ & $\begin{array}{r}0.1786 \\
(1.68) \\
\end{array}$ & $\begin{array}{r}0.1173 \\
(1.24) \\
\end{array}$ \\
\hline GDP Per capita & $\begin{array}{l}0.0013 \\
(0.69) \\
\end{array}$ & $0.0003 \quad(0.14)$ & $\begin{array}{l}0.0008 \\
(0.45) \\
\end{array}$ & $\begin{array}{l}0.0006 \\
(0.32) \\
\end{array}$ & $\begin{array}{r}-0.0016 \\
(-0.82) \\
\end{array}$ & $0.0009 \quad(0.48)$ \\
\hline $\begin{array}{l}\text { Domestic credit } \\
\text { to private sector }\end{array}$ & $\begin{array}{l}-0.1377 \\
(-1.06)\end{array}$ & $\begin{array}{l}-0.1258 \\
(-0.98)\end{array}$ & $\begin{array}{l}-0.0960 \\
(-0.74)\end{array}$ & $\begin{array}{r}-0.1209 \\
(-0.93)\end{array}$ & $\begin{array}{l}-0.1125 \\
(-0.88)\end{array}$ & $\begin{array}{l}-0.1509 \\
(-1.18)\end{array}$ \\
\hline Wald-test & $\begin{array}{l}\chi 2(18)=333.0 \\
\text { Prob }>\text { chi } 2=0.000\end{array}$ & $\begin{array}{l}\chi 2(18)=344.8 \\
\text { Prob }>\text { chi } 2=0.00\end{array}$ & $\begin{array}{l}\chi 2(18)=346.4 \\
\text { Prob }>\text { chi } 2=0.00\end{array}$ & $\begin{array}{l}\chi 2(18)=334.7 \\
\text { Prob }>\text { chi } 2=0.00\end{array}$ & $\begin{array}{l}\chi 2(18)=350.5 \\
\text { Prob }>\text { chi } 2=0.00\end{array}$ & $\begin{array}{l}\chi 2(18)=336.7 \\
\text { Prob }>\text { chi } 2=0.00\end{array}$ \\
\hline Sargan-test ${ }^{\mathrm{a}}$ & $\begin{array}{l}\chi 2(30)=32.22 \\
\text { Prob }>\text { chi } 2=0.75\end{array}$ & $\begin{array}{l}\chi 2(30)=29.01 \\
\text { Prob }>\text { chi } 2=0.86\end{array}$ & $\begin{array}{l}\chi 2(30)=31.47 \\
\text { Prob }>\text { chi } 2=0.77\end{array}$ & $\begin{array}{l}\chi 2(30)=34.74 \\
\text { Prob }>\text { chi } 2=0.92\end{array}$ & $\begin{array}{l}\chi 2(30)=33.48 \\
\text { Prob }>\text { chi } 2=0.59\end{array}$ & $\begin{array}{l}\chi 2(30)=36.40 \\
\text { Prob }>\text { chi } 2=0.89\end{array}$ \\
\hline $\operatorname{AR}(1)^{b}$ & $\begin{array}{l}\mathrm{z}=-3.8406 \\
\mathrm{p} \text {-value }=0.000\end{array}$ & $\begin{array}{l}\mathrm{z}=-3.8406 \\
\mathrm{p} \text {-value }=0.000\end{array}$ & $\begin{array}{l}z=-3.6658 \\
p \text {-value }=0.000\end{array}$ & $\begin{array}{l}z=-3.7941 \\
p \text {-value }=0.000\end{array}$ & $\begin{array}{l}z=-3.7252 \\
p \text {-value }=0.000\end{array}$ & $\begin{array}{l}\mathrm{z}=-3.8153 \\
\mathrm{p} \text {-value }=0.000\end{array}$ \\
\hline $\operatorname{AR}(2)^{c}$ & $\begin{array}{l}\mathrm{z}=0.5776 \\
P \text {-value }=0.5635\end{array}$ & $\begin{array}{l}\mathrm{z}=0.5003 \\
P \text {-value }=0.6168\end{array}$ & $\begin{array}{l}\mathrm{z}=0.3409 \\
\text { p-value }=0.7332\end{array}$ & $\begin{array}{l}\mathrm{z}=0.5478 \\
\text { p-value }=0.5838\end{array}$ & $\begin{array}{l}\mathrm{z}=0.3861 \\
\text { p-value }=0.6994\end{array}$ & $\begin{array}{l}\mathrm{z}=0.4658 \\
p \text {-value }=0.6413\end{array}$ \\
\hline Observations & 179 & 179 & 179 & 179 & 179 & 179 \\
\hline
\end{tabular}

This Table presents estimations performed using Blundell and Bond (1998) two-step system robust GMM estimator. For the definition of the variables see Table 1. Robust $\mathrm{z}$ values are in parentheses and significance at $10 \%, 5 \%$, and $1 \%$ level is noted by $* * *$ and $* * *$ respectively.

a Test for over-identifying restrictions in GMM dynamic model estimation.

${ }^{\mathrm{b}}$ Arellano-Bond test that average autocovariance in residuals of order 1 is 0 (H0: no autocorrelation).

${ }^{c}$ Arellano-Bond test that average autocovariance in residuals of order 2 is 0 (H0: no autocorrelation).

\subsection{Robustness check}

In order to test the robustness of the results, we carry out some alternative regressions. We estimate fixed effect regressions as a robustness test for the results with the GMM system method, at least for the sign of the coefficients and the results are reported in Table 5. Using fixed effect regressions does not fundamentally change the picture. The significance and the direction of influence of the governance variables shown in the estimations are preserved. Since the proxies for institutional difference are highly correlated, and qualitatively yield the same result, we present only results for one of the proxies.

Table 5: Robustness results (dependent variable: ROA)

\begin{tabular}{|l|l|l|}
\hline Variable & Notation & Fixed effects model \\
\hline Intercept & & $\begin{array}{l}1.0475 \\
(1.14)\end{array}$ \\
\hline Log Age & AG & $\begin{array}{l}-0.0021 \\
(-0.82)\end{array}$ \\
\hline Log size & S & $0.0164^{* * *}$ \\
& & $(2.77)$ \\
\hline Capital & CAP & $0.2466^{* * *}$ \\
& & $(5.37)$ \\
\hline Gearing & GR & $0.0058^{* * *}$ \\
& & $(2.39)$ \\
\hline Deposits to assets & DepAsse & $0.1530^{*}$ \\
& & $(1.75)$ \\
\hline Efficiency & EFF & $-0.3512^{* * *}$ \\
& & $(-7.58)$ \\
\hline Portfolio at risk & PAR & $-0.1391^{* * *}$ \\
& & $(-2.82)$ \\
\hline Loan size & LS & -0.0122 \\
& & $(-0.70)$ \\
\hline
\end{tabular}




\begin{tabular}{|l|l|l|}
\hline Variable & Notation & Fixed effects model \\
\hline Share of lending to women & Wom & 0.0508 \\
& & $(1.14)$ \\
\hline Control of Corruption & COR & $-0.1410^{* * *}$ \\
& & $-2.91)$ \\
\hline Business Freedom & BF & -0.0003 \\
& & $(-0.43)$ \\
\hline Property Rights & PR & -0.0003 \\
& & $(-0.24)$ \\
\hline Share of rural population & RURALPOP & $-0.0164^{*}$ \\
& & $(-1.81)$ \\
\hline Inflation expectations & INF & 0.1235 \\
& & $(0.98)$ \\
\hline GDP Per capita & GDP & 0.0022 \\
& & $(1.16)$ \\
\hline Domestic credit to private sector & PCRED & -0.2147 \\
\hline R2 & & $(-1.64)$ \\
\hline Number of obs & & 0.6287 \\
\hline
\end{tabular}

\section{Conclusion}

This paper has taken a first empirical step to examine the role of institutional context on influencing microfinance profitability in Africa. The paper is pioneering in using dynamic GMM estimators and two-step estimation method, in analyzing the impact of institutions on MFI profitability. The contribution relative to the existing literature is the treatment of potential endogeneity biases. The paper provides first empirical justification for the hypothesis that microfinance profitability is non-negligibly driven by the surrounding institutional environment. Estimation results show that the positive effect political stability and rule of law has on profitability of younger MFIs is mitigated by the reduction in profitability of older MFIs. This findings highlights the critical importance of information capital in both developing microfinance industry and reducing excess liquidity. Perhaps the most interesting result is that corruption makes it harder for MFIs to realize profits, irrespective of MFI age. Results also indicate that growth of portfolio to assets ratio may be slower where there is more corruption which is consistent with corruption acting as a barrier to micro-enterprise activities, at least in start-up if not on subsequent growth.

Well developed institutions may actually make it less costly for MFIs to operate in a fully compliant way which would be consistent with arguments that favour relaxed regulations for MFIs. At the macro level, control of corruption will not have beneficial effects on microfinance profitability, unless it is also accompanied by policies that improve the informational capital of young MFIs. The evidence adduced in this paper may help guide the sequencing of institutional reforms that could promote microfinance performance. However, due to limited resources and cultural factors across the African setting, institutions can only be reformed slowly. It is therefore prudent that policymakers prioritize the institutional reforms that would steer MFIs profitability. A policy prescription tailored towards MFI specific factors and institutional environment may invigorate the industry and subsequently profitability.

\section{References}

Acemoglu, D and Johnson, S (2005). Unbundling Institutions, Journal of Political Economy, 113:949-95.

Acemoglu, D, Johnson, S and Robinson, J (2001). The colonial origins of comparative development, American Economic Review, 91:5, 1369-401.

Ahlin, C and Jiang, N (2008). Can micro-credit bring development? Journal of Development Economics, 86:121

Ahlin, C., Lin, J and Maio, M (2011). Where does microfinance flourish? Microfinance institution performance in macroeconomic context, Journal of Development Economics, 95:105-120

Alence, R. (2004). Political institutions and developmental governance in sub-Saharan Africa. The Journal of Modern African Studies, 42:163.

Anayiotos, G and Toroyan, H., (2009). Institutional factors and financial sector development: Evidence from Sub-Saharan Africa, IMF Working Paper No. 09/258

Anayiotos, G and Toroyan, H., (2009). Institutional Factors and Financial Sector Development: Evidence from Sub-Saharan Africa, IMF Working Paper No. 09/258

Armantiera, O. and Amadou B (2011). A controlled field experiment on corruption. European Economic Review, 


\section{5:1072-1082.}

Armendáriz de Aghion, B. and J. Morduch (2010). The Economics of Microfinance, second edition MIT Press, Cambridge, Massachusetts.

Aron, J (2000). Growth and Institutions: A review of the evidence, the World Bank Research Observer, 15:99135

Arun, T and Annim, S (2010). Economic governance of MFIs: inside the black box, Brooks World Poverty Institute working paper series number 138, The University of Manchester.

Arun, T and Hulme, D (2008). Microfinance-A way forward, Brooks World Poverty Research Institute Working Paper No.54, The University of Manchester.

Baltagi, B and Song, I. (2006). 'Unbalanced panel data: A survey'. Statistical Papers, 47:493-523

Barseghyan, L. (2008). Entry costs and cross-country differences in productivity and output. Journal of Economic Growth, 13:145-167.

Bartha,J, Lin, C, Lin, P and Song, F (2009). Corruption in bank lending to firms: Cross-country micro evidence on the beneficial role of competition and information sharing. Journal of Financial Economics, 91:361-388

Beck, T., Cull, R. and Jerome, A. (2005). 'Bank privatization and performance: empirical evidence from Nigeria', Journal of Banking and Finance, 29:2355-79.

Behr, P., Entzian, A., Güttler, A (2011). How do lending relationships affect access to credit and loan conditions in microlending? Journal of Banking and Finance, 35: 2169-2178

Bevan A, Estrin S, Meyer K (2004). Foreign investment location and institutional development in transition economies. International Business Review, 13:43-64

Bianca, C., Kraay., A and Nyiri, Z (2009). "Corruption and confidence in public institutions: Evidence from a global survey". World Bank Policy Research Department Working Paper No. 5157, Washington, DC, World Bank

Bissessar, N (2009). Does corruption persist in Sub-Saharan Africa? International Advances in Economic Research, 15:336-350.

Blundell, R and Bond, S. (1998). 'Initial conditions and moment restrictions in dynamic panel data models,' Journal of Econometrics, 87:115-143.

Cai, H., Hanming, F., and Lixin, C. (2011). Eat, drink, firms, government: an investigation of corruption from entertainment and travel costs of Chinese firms. Journal of Law and Economics, 54: 55-78

Catterberg, G and Moreno, A (2005). The individual bases of political trust: trends in new and established democracies, International Journal of Public Opinion Research, 18:408-443.

Caudill, S, Gropper D, and Hartarska V. (2009), "Which microfinance institutions are becoming more costeffective with time? Evidence from a mixture model," Journal of Money, Credit, and Banking, 41:651-672.

Chang, E and Chu, Y (2006). Corruption and trust: exceptionalism in Asian democracies? The Journal of Politics, 68:259-271

Cheryl, L. (2010). Does the rights hypothesis apply to China? Journal of Law and Economics, 53 (4)

Cho, W and Kirwin, M (2007). A Vicious cycle of corruption and mistrust in institutions in Sub-Saharan Africa: A Micro-Level Analysis, Afrobarometer Working Paper, No. 71, Michigan State University.

Chu M. (2007). Commercial returns at the Base of the Pyramid. Innovations Technology Governance Globalization 2:115-146.

Ciccone, A and Papaioannou, E. (2007). Red tape and delayed entry. Journal of the European Economic Association, 5:444-458.

Claessens, S, and Laeven, L. (2003). Financial development, property rights and growth. Journal of Finance, 58:2401-2436.

Clausen, B., Kraay, A and Nyiri, Z., (2009). Corruption and Confidence in Public Institutions Evidence from a Global Survey, Policy Research Working Paper 5157, the World Bank

Crafts, N. (2006). Regulation and productivity performance. Oxford Review of Economic Policy, 22:186-202.

Creane, S., Goyal, R., Mushfiq M, Randa S., (2004)."Financial Development in the Middle East and North Africa," IMF Working Paper 04/201.

Cull, R., Demirgüc-Kunt, A and Morduch, J. (2007). 'Financial performance and outreach: a global analysis of leading microbanks', Economic Journal, 117:F107-F133.

Cull, R., Demirgüc-Kunt, A and Morduch, J. (2009a). 'Microfinance meets the market' Journal of Economic Perspectives, 23:167-192.

Cull, R., Demirgüç-Kunt, A., Morduch, J., (2009b). Banks and microbanks, World Bank Policy Research Working Paper Series No 5078, The World Bank

Cull, R., Demirgüc-Kunt, A and Morduch, J. (2009c). Microfinance trade-offs regulation, competition, and financing. World Bank Policy Research Working Paper 5086. Washington, DC: World Bank.

Cull, R., Demirgüc-Kunt, A., and Morduch, J. (2011). Does regulatory supervision curtail microfinance profitability and outreach? World Development, 39: 949-965. 
D’Espallier, B., Guérin, I and Mersland, R (2010). Gender bias in microfinance, World Development, forthcoming

D’Espallier, B., Guérin, I and Mersland, R (2011) 'Women and Repayment in Microfinance'. World Development, 39:758-772

De Soto H. (2000). The mystery of capital: Why capitalism triumphs in the West and fails everywhere else. Basic Books: New York.

Damania, R., Fredriksson, P.G. and Mani, M. (2004). The persistence of corruption and regulatory compliance failures: theory and evidence. Public Choice, 121:363-390.

Demetriades, Panicos and D. Fielding, (2011). Information, institutions and banking sector development in West Africa. Economic Inquiry, DOI: 10.1111/j.1465-7295.2011.00376.x

Demirguc-Kunt, A., Inessa L., and Maksimovic, V. (2006). Business environment and the incorporation decision. Journal of Banking and Finance, 30: 2967-93.

Demirgüc-Kunt, A., Laeven, L., Levine, R (2004). "Regulations, Market Structure, Institutions, and the Cost of Financial Intermediation", Journal of Money Credit and Banking, 36:593-622

Dietsche, E. (2007). The quality of institutions: a cure for the 'resource curse'? July, Centre for Energy, Petroleum and Mineral Law and Policy, University of Dundee, Oxford Policy Institute.

Dixit, A. (2009). 'Governance institutions and economic activity'. American Economic Review, 99:5-24.

Djankov, S. (2009). The regulation of entry: A survey. World Bank Research Observer, 24:183-203.

Djankov, S., McLiesh, C., and Shleifer, A (2007). Private credit in 129 Countries, Journal of Financial Economics, 84:299-329.

Djankov, S., Y. Qian, G. Roland and E. Zhuravskaya (2006). "Who are China's entrepreneurs?" American Economic Review, 96:348-352.

Dreher, A and Schneider, F.G (2010). Corruption and the shadow economy: an empirical analysis, Public Choice, 144:215-238

Fisman, R and Svensson, J (2007). Are corruption and taxation really harmful to growth? Firm-level evidence. Journal of Development Economics, 83:63-75.

Gani, A. and Ngassam, C (2008). Effect of institutional factors on stock market development in Asia, American Journal of Finance and Accounting, 1:103-120.

Gelos, R.G. and Wei, S.J. (2006). Transparency and international investor behaviour, IMF Working Paper $02 / 174$.

Gioacchino, D and Franzini, M (2008). Bureaucrats' corruption and competition in public administration, European Journal of Law and Economics, 26:291-306

Hallward-Driemeier, M (2009). Who survives? The impact of corruption, competition and property rights across firms, World Bank Policy Research Working Paper 5084

Hartarska V. (2009). The impact of outside control in microfinance, Managerial Finance, 35 (12)

Hartarska V. and Nadolnyak, D (2008). "An impact analysis of microfinance in Bosnia," World Development, 26:2605-2619.

Hartarska, V. (2005). "Governance and performance of microfinance institutions in Central and Eastern Europe and the Newly Independent States," World Development, 33:1627-1643.

Hartarska, V., and D. Nadolnyak (2007). 'Do regulated microfinance institutions achieve better sustainability and outreach? Cross-country evidence', Applied Economics, 39:1207-122

Hasan, I., Haizhi, W, and Mingming, Z (2009). "Do better institutions improve bank efficiency? Evidence from a transitional economy", Managerial Finance, 35: 107-127

Ito, H. (2006). Financial Development and Financial Liberalization in Asia: Thresholds, Institutions and the Sequence of Liberalization, The North American Journal of Economics and Finance, 17:303-327.

Johnson, S., McMillan, J and Woodruff, C (2002). Property rights and finance. American Economic Review, 92:1335-1356.

Kaboski, J., and Townsend, R. (2005). 'Policies and impact: An analysis of village-level microfinance institutions', Journal of the European Economic Association, 3:1-50.

Kaufmann, D. and Kraay, A. (2002). Growth without governance. Economica, 3:169-229.

Kaufmann, D., Kraay, A., Mastruzzi, M., (2009). Governance Matters V: Governance Indicators for 1996-2008. Available from :http://info.worldbank.org/governance/wgi/resources.htm

Klapper, L., Laeven, L and Rajan, R (2006). Entry regulation as a barrier to entrepreneurship." Journal of Financial Economics, 82:591-629.

Knack, S and Keefer. P (1995). "Institutions and economic performance: cross-country tests using alternative institutional measures." Economics and Politics, 7:207-27.

Knox, C. (2009). Dealing with sectoral corruption in Bangladesh: developing citizen involvement, Public Administration and Development, 29:117-132.

La Porta, R., F. Lopez-de-Silanes, A. Shleifer and R. Vishny (2002). Investor Protection and Corporate 
Valuation, Journal of Finance, 57:1147-1170.

La Porta, R., Lopez-de-Silanes, F and Shleifer, A. (2008). The economic consequences of legal origins. Journal of Economic Literature, 46:285-332.

La Porta, R., Lopez-de-Silanes, F.., Shleifer, A and Vishny, R. (1998). “Law and Finance,” Journal of Political Economy, 106:1113-1155.

La Porta, R., Lopez-de-Silanes, F.., Shleifer, A and Vishny, R. (2000). "Investor Protection and corporate governance." Journal of Financial Economics, 58:3-28.

Laeven, L and Woodruff, C (2008). The Quality of the legal system, firm ownership, and firm size, Working paper, IMF, Washington, DC.

Lafourcade, A.C., J, Isern., P, Mwangi and M, Brown (2006). Overview of the outreach and financial performance of microfinance institutions in Africa, Microbanking Bulletin, April

Lambsdorff, J (2007). The institutional economics of corruption and reform. Theory, evidence, and policy, Cambridge: Cambridge University Press.

Lensink, R., Meesters, A., Naaborg, I (2008). Bank efficiency and foreign ownership: Do good institutions matter? Journal of Banking and Finance, 32:834-844

Levine, R, (2005). In: Aghion, Philippe, Durlauf, Steven N. (Eds.), Handbook of Economic Growth. Finance and growth, volume 1A. Elsevier Press.

Licht, A., Goldschmidt, C., Schwartz, S (2007). Culture rules: The foundations of the rule of law and other norms of governance. Journal of Comparative Economics, 35:659-688

Loayza, N., Oviedo, A and Serven, L. (2005). Regulation and macroeconomic performance. World Bank Working Paper 3469.

Long, C. (2010). Does the rights hypothesis apply to China? Journal of Law and Economics, 53:629-650

McDonald, C and Schumacher, L (2007). Financial Deepening in Sub-Saharan Africa: Empirical evidence on the role of creditor rights protection and information sharing, International Monetary Fund, Working Paper $07 / 203$

McIntosh, C., De Janvry, A and Sadoulet, E. (2005). 'How rising competition among microfinance institutions affects incumbent lenders', The Economic Journal, 115:987-1004.

Mersland, R (2009a). The governance of non-profit micro finance institutions: lessons from history, Journal of Management and Governance doi: 10.1007/s10997-009-9116-7

Mersland, R (2009b). "The cost of ownership in microfinance organizations," World Development, 37:469-478

Mersland, R and Strøm, R. (2009). 'Performance and governance in microfinance institutions', Journal of Banking and Finance, 33:662-669

Mersland, R and Strøm, R., (2008). Performance and trade-offs in microfinance organisations-does ownership matter? Journal of International Development, 20:598-612.

Messick, R. (1999) "Judicial reform and economic development: a survey of the issues," World Bank Research Observer, 14:117-136.

Mosley, P. and Rock, J. (2004). 'Microfinance, labour markets and poverty in Africa: A study of six institutions', Journal of International Development, 16:467-500.

Muriu, P.W (2012). What explains the low profitability of microfinance institutions in Africa? African Journal of Social Sciences, 2:85-115

Ng, D. (2006). 'The impact of corruption on financial markets'. Managerial Finance, 32:822-836

North, DC (1990). Institutions, institutional change and economic performance. Cambridge University Press, Cambridge

Olken, B (2007). "Monitoring corruption: Evidence from a field experiment in Indonesia." Journal of Political Economy 115:200-249.

Patten, R., Rosengard, J and Johnston, D (2001). Microfinance Success amidst Macroeconomic Failure: The Experience of Bank Rakyat Indonesia During the East Asian Crisis World Development, 29:1057-1069

Pierre-Guillaume, M and Sekkat, K (2005): Does corruption grease or sand the wheels of growth? Public Choice, 122:69-79.

Qian, J and Strahan, P (2007). How law and institutions shape financial contracts: The case of bank loans, Journal of Finance, 62:2803-2834.

Rajan, R and Zingales, L (2003). The Great reversals: The politics of financial development in the Twentieth Century, Journal of Financial Economics, 69:5-50.

Raymond, F and Jakob, S (2007). Are corruption and taxation really harmful to growth? Firm-level evidence. Journal of Development Economics, 83:63-75

Ritzen, J., Easterly, W. and Woolcock, M. (2000). On 'good' politicians and 'bad' policies: social cohesion institutions, and growth. World Bank Policy Research Working Paper 2248, Washington, DC, World Bank.

Rivera-Santos M, Rufín C, Kolk A. (2012). Bridging the institutional divide: Partnerships in subsistence markets. Journal of Business Research 65:1721-1727. 
Roe, M. and Siegel, J. (2011). Political Instability: Its effects on financial development, its roots in the severity of economic inequality, Journal of Comparative Economics, 39:279-309

Svensson, J., (2005). Eight questions about corruption. Journal of Economic Perspectives, 19:19-42.

Weill, L (2011a). How corruption affects bank lending in Russia, Economic Systems, 35:230-243.

Weill, L (2011b). Does corruption hamper bank lending? Macro and micro evidence, Empirical Economics, 41:25-42.

\section{Appendix}

Table 1: Tests for time and country-specific effects

\begin{tabular}{|l|l|l|}
\hline Model & LM test & P-value \\
\hline$D_{2}=D_{3}=\ldots \ldots . . D_{C}=0$ & $\chi^{2}(30)=126.20$ & 0.8200 \\
\hline$\gamma_{2}=\gamma_{3}=\ldots \ldots \ldots \gamma_{T}$ & $\chi^{2}(11)=4.19$ & 0.7990 \\
\hline$D_{2}=D_{3}=\ldots \ldots . . D_{C}=\gamma_{2}=\gamma_{3}=\gamma_{t}=0$ & $\chi^{2}(41)=35.44$ & 0.8910 \\
\hline
\end{tabular}

Where $D_{c}$ represent country dummies and $\gamma_{t}$ time dummies.

Table 2: Description of the panel (MFIs per year)

\begin{tabular}{|l|l|}
\hline 1997 & 10 \\
\hline 1998 & 19 \\
\hline 1999 & 30 \\
\hline 2000 & 42 \\
\hline 2001 & 90 \\
\hline 2002 & 125 \\
\hline 2003 & 146 \\
\hline 2004 & 159 \\
\hline 2005 & 186 \\
\hline 2006 & 178 \\
\hline 2007 & 155 \\
\hline 2008 & 167 \\
\hline
\end{tabular}

